\title{
PEMANFAATAN PUPUK BOKASIH TERHADAP PENINGKATAN KESUBURAN FISIK DAN KIMIA TANAH PADA LAHAN PEMBUDIDAYAAN TANAMAN TOMAT (Lycopersicum esculentum MILL.)
}

\author{
Paulus O Lana, Charly Mutiara \\ Program Studi Agroteknologi, Fakultas Pertanian-Universitas Flores \\ Charlyinter1988@Gmail.com
}

\begin{abstract}
This study aims to determine the effect of bokashi fertilizer dosage on the physical and chemical properties of soil on tomato plants and the optimum dose of bokashi fertilizer which can provide the best influence on the physical and chemical properties of the soil. The research design used was a randomized block design (RBD) with a single factor pattern consisting of five treatments namely $\mathrm{B} 0=0$ tons $\mathrm{ha}^{-1}$ bokashi fertilizer (control), B1 $=5$ tons ha ${ }^{-1}$ bokashi fertilizer, B2 $=10$ tons ha $^{-1}$ bokashi fertilizer, B3 = 15 tons $\mathrm{ha}^{-1}$ bokashi fertilizer, B4 $=20$ tons $\mathrm{ha}^{-1}$ bokashi fertilizer. The observation variables in this study were soil volume/bulk density $\left(\mathrm{gr} / \mathrm{cm}^{3}\right)$, total soil pore space (\%), N-total soil, available $\mathrm{P}$-soil, available $\mathrm{K}$-soil, soil C-organic, and soil $\mathrm{pH}$. The results showed that the administration of bokashi fertilizer was able to improve the physical properties of soil in tomato plants, namely the weight of the soil volume decreased by $1,120 \mathrm{gr} / \mathrm{cm}^{3}$, water holding capacity increased by $30.24 \%$, and soil pore space increased by $57.74 \%$, so that the soil aggregate became good Giving doses of bokashi fertilizer can improve soil chemical properties in tomato plants, namely C-organic $0.91 \%$ very low, $\mathrm{N}$-total soil $0.32 \%$ medium, $\mathrm{P}$-available $37.25 \mathrm{ppm}$ very high, and K-available $425.64 \mathrm{ppm}$ very high and soil $\mathrm{pH}$ to 6.81 neutral. The supply of 20 tons/ha of bokashi fertilizer can improve soil physical and chemical properties optimally in tomato plants.
\end{abstract}

Keywords: Bokashi, Physical and Chemical Properties of Soil, Tomatoes.

\section{PENDAHULUAN}

Tomat (Lycopersicum esculentum Mill.) merupakan salah satu komoditas sayuran yang mempunyai prospek pasar yang cerah (Hamidah, 2014). Data tentang produktivitas Berdasarkan data dari Dinas Pertanian Nasional dan Kabupaten Ende, pada tahun 2015 dan 2016 produktivitas tomat di Kabupaten Ende masih jauh lebih rendah dari Produktivitas nasional (Dinas Pertanian Tanaman Pangan Indonesia Tahun, 2016; Dinas Pertanian Tanaman Pangan Kab Ende, 2016). Salah satu penyebab penurunan produktifitas tanaman adalah terjadinya degradasi lahan sehingga menyebabkan kandungan unsur hara dalam tanah rendah. Upaya yang dapat dilakukan adalah dengan diberikannya pupuk organik seperti bokasih.

Pupuk bokasih merupakan salah satu jenis pupuk organik yang memiliki biomasa dengan kandungan hara yang cukup $(1,2 \% \mathrm{~N}$, 0,5 \% P dan 0,3 \% K) (Hartanto, 2013). Hasil penelitian dengan memanfaatkan pupuk bokasih telah dilakukan oleh Nurlenawati dkk (2010). Berdasarkan hasil penelitian tersebut diketahui bahwa penggunaan pupuk Bokasih jerami limbah jamur merang 10 ton/ha memberikan pengaruh terhadap pertumbuhan 
dan hasil tanaman tomat yang paling baik (Nurlenawati, dkk, 2010). Berdasarkan uraian di atas maka penelitian tentang pemanfaatan pupuk bokasih terhadap peningkatan kesuburan fisik dan kimia tanah pada lahan pembudidayaan tanaman Tomat (Lycopersicum esculentum Mill.) perlu untuk dilakukan. tanah pada lahan pembudidayaan tanaman Tomat (Lycopersicum esculentum Mill.) perlu untuk dilakukan.

\section{METODE PENELITIAN Tempat danWaktu}

Percobaan ini dilaksanakan di desa Dile, Kecamatan Detusoko, Kabupaten Ende. dengan ketinggian tempat $\pm 600-1200$ mdpl, curah hujan rata-rata $1.508-2.750$ $\mathrm{mm} /$ tahun. Hasil analisis tanah awal meliputi PH 5,82 C Organik 1,56\%, N total 0,13\%, P tersedia 17,56 ppm, $\mathrm{K}$ tersedia 145,56 ppm,kadar air 26,54\%, pasir 59,45\%, debu $30,24 \%$, liat10,31\%. Waktu penelitian dimulai dari bulan Februari sampai Mei 2016.

\section{Bahan dan Alat}

Bahan - bahan yang digunakan dalam percobaan ini adalah benih tomat varietas tamindo, dan pupuk bokasih. Alat - alat yang digunakan dalam pengambilan sampel tanah adalah ring sampel, kantong plastik, pisau kater, tova, tali rafia dan alat tulis.

\section{Rancangan Penelitian}

Rancangan yang digunakan dalam penelitian ini adalah rancangan acak kelompok (RAK) dengan pola faktor tunggal yang terdiri dari lima perlakuan yaitu:

B0 : Tanpa pupuk bokasih

B1 : 5 ton $\mathrm{ha}^{-1}$ pupuk bokasih

B2 : 10 ton ha $^{-1}$ pupuk bokasih

B3 : 15 ton $\mathrm{ha}^{-1}$ pupuk bokasih

B4 : 20 ton ha ${ }^{-1}$ pupuk bokasih

Semua perlakuan diulang sebanyak empat kali sehingga terdapat 20 petak percobaan.

\section{Pelaksanaan Penelitian}

Pelaksanaan penelitian meliputi beberapa tahap yaitu persiapan lahan, persemaian, pemupukan, penanaman, pemeliharaan tanaman, panen dan pengambilan sampel tanah.

\section{Variabel Pengamatan}

Variabel yang diamati dalam penelitian ini terdiri dari sifat fisik tanah seperti berat volume tanah $\left(\mathrm{gr} / \mathrm{cm}^{3}\right)$, Total Ruang Pori Tanah (\%), dan Kadar Air tanah. Sedangkan variable pada sifat kimia tanah adalah $\mathrm{N}$ - total tanah, P-tersedia tanah, K-tersedia tanah, Corganik tanah dan $\mathrm{pH}$ tanah

\section{Analisis Data}

Data hasil pengamatan yang diperoleh merupakan data hasil analisis laboratorium dari setiap sampel tanah yang dikumpulkan secara komposit. Data hasil analisis laboratorium kemudian dideskripsikan berdasarkan kriteria sifat kimia tanah.

\section{HASIL DAN PEMBAHASAN Sifat Fisik Tanah}

Pengaruh Sifat Fisik Tanah dapat di lihat pada Tabel 4.1 di bawah ini : 
Tabel 4.1 Hasil Analisis Sifat Fisik Tanah

\begin{tabular}{ccccc}
\hline \multirow{2}{*}{ Perlakuan } & $\begin{array}{c}\text { Berat Volume Tanah } \\
\left(\mathrm{gr} / \mathrm{cm}^{3}\right)\end{array}$ & \multicolumn{2}{c}{ Kadar Air Tanah } & Ruang Pori Tanah \\
\cline { 3 - 4 } & 1.436 & KU $(\%)$ & KL $(\%)$ & 44.79 \\
B0 & 1.403 & 9.410 & 26.540 & 47.06 \\
B1 & 1.312 & 10.540 & 25.640 & 50.49 \\
B2 & 1.241 & 11.490 & 29.640 & 53.17 \\
B3 & 1.120 & 12.150 & 30.570 & 57.74 \\
B4 &
\end{tabular}

Keterangan : KU : Kering Udara, KL : Kapasitas Lapang

Pada tabel 4.1 menunjukan bahwa pengaruh faktor pemakaian dosis pupuk bokasih dapat menurunkan berat volume tanah dari dosis 0 ton/ha - 20 ton/ha. Semakin tinggi dosis pupuk bokasih, maka makin kecil pula berat volume tanah. Penurunan berat volume tanah dapat terjadi karena bokasih merupakan bahan organik hasil fermentasi yang strukturnya masih belum terlapuk sempurna, sehingga jika ditambahkan kedalam tanah akan menambah gembur tanah tersebut (Iskandar, 2003 ; Hanafiah, 2010).

Pengaruh faktor pemakaian dosis pupuk bokasih juga dapat meningkatkan daya pegang air tanah dari dosis 5 ton $\mathrm{ha}^{-1}$ ke dosis 20 ton $\mathrm{ha}^{-1}$. Pupuk bokasih yang memiliki bahan organik yang sudah terdekomposisi karena proses fermentasi mampu memperbaiki daya pegang air dalam tanah (Hanafiah, 2010).

Berdasarkan data tersebut dapat dipahami bahwa pupuk bokasih mampu menaikan ruang pori tanah awal 44,79\% menjadi 57.74 $\%$ pada dosis 20 ton/ha. Pupuk bokasih yang diberikan mengandung bahan organik yang ketika berada di dalam tanah dapat meningkatkan agregasi tanah, sehingga porositasnya meningkat (Hanafiah, 2010)

\section{Sifat Kimia Tanah}

Pengaruh Sifat Kimia Tanah dapat di lihat pada Tabel 4.2 di bawah ini.

Tabel 4.2 Hasil Analisis Sifat Kimia Tanah

\begin{tabular}{cccccc}
\hline Perlakuan & $\begin{array}{c}\text { C Organik } \\
(\%)\end{array}$ & N Total $(\%)$ & $\begin{array}{c}\text { P Tersedia } \\
(\mathrm{ppm})\end{array}$ & $\begin{array}{c}\text { K Tersedia } \\
(\mathrm{ppm})\end{array}$ & $\mathrm{pH}$ \\
\hline B0 & $1.56(\mathrm{R})$ & $0.13(\mathrm{R})$ & $17.56(\mathrm{~S})$ & $145.56(\mathrm{~S})$ & $5.8(\mathrm{AM})$ \\
$\mathrm{B} 1$ & $1.29(\mathrm{R})$ & $0.14(\mathrm{R})$ & $20.35(\mathrm{~S})$ & $154.49(\mathrm{~S})$ & $5.9(\mathrm{AM})$ \\
B2 & $1.65(\mathrm{R})$ & $0.17(\mathrm{R})$ & $24.54(\mathrm{~S})$ & $190.24(\mathrm{~S})$ & $6.1(\mathrm{AM})$ \\
B3 & $0.89(\mathrm{SR})$ & $0.25(\mathrm{~S})$ & $32.65(\mathrm{~T})$ & $315.00(\mathrm{~T})$ & $6.2(\mathrm{AM})$ \\
B4 & $0.96(\mathrm{SR})$ & $0.32(\mathrm{~S})$ & $37.25(\mathrm{ST})$ & $425.64(\mathrm{ST})$ & $6.8(\mathrm{~N})$ \\
\hline Keterangan: & R : Rendah & S : Sedang & \multicolumn{2}{c}{ : Tinggi } & \\
& ST : Sangat Tingi & M : Masam & Agak Masam &
\end{tabular}


Pemberian perlakuan pupuk bokasih 20 ton ha $^{-1}$ dapat menurunkan kadar C-organik tanah sebesar $0.96 \%$ dibandingkan dengan perlakuan tanpa pupuk atau kontrol. Penurunan C-organik tanah terjadi karena pupuk bokasih mengandung mikroorganisme yang (Hartanto, 2013). Mikroorganisme tersebut akan meningkatkan dekomposisi bahan organik sehingga kadar C-organik tanah menjadi semakin berkurang.

Peran pupuk bokasih dalam meningkatkan $\mathrm{N}$ Total tanah terjadi seiring dengan penambahan dosis pupuk bokasih (Tabel 4.2). Hal ini dapat terjadi karena mikroba - mikroba di dalam pupuk dapat berperan dalam pengikatan $\mathrm{N}$ bagi tanah. Mekanisme peningkatan $\mathrm{P}$ tersedia dan $\mathrm{K}$ tersedia di dalam tanah juga serupa dengan peningkatan $\mathrm{N}$ total tanah. Yakni karena peningkatan dekomposisi bahan organik yang ada dalam pupuk maupun ada di dalam tanah. Selain itu dengan kehadiran pupuk organik, akan terjadi peningkatan koloid organik (Hanafiah, 2010). Koloid organik ini berperan dalam menjaga agar unsur hara tetap terjaga di dalam tanah sehingga tersedia bagi tanaman. Berkaitan dengan peningkatan $\mathrm{P}$ tersedia, hal ini dapat terjadi juga karena hasil dekomposisi bahan organik adalah asam-asam organik yang dapat memutuskan ikatan $\mathrm{P}$ yang ada di dalam tanah, sehingga menjadi tersedia di dalam tanah.
Pengaruh pemberian pupuk organik bokasih dalam menjaga perubahan $\mathrm{pH}$ tanah adalah sangat penting. Hal ini terjadi karena bahan organik yang ada di dalam tanah dapat berperan sebagai buffer (penyangga) bagi $\mathrm{pH}$ tanah (Hanafiah, 2010). Dengan adanya bahan organik ini, maka $\mathrm{pH}$ tanah akan terjaga dari adanya perubahan. Hal inilah yang mengakibatkan tanah yang telah diberikan pupuk bokasih dengan dosis yang tertinggi yakni 20 ton ha $^{-1}$ memiliki $\mathrm{pH}$ yang netral, dibandingkan dengan perlakuan lainnya.

\section{SIMPULAN}

\section{Kesimpulan}

1. Pemberian pupuk bokasih mampu memperbaiki sifat fisik tanah pada tanaman tomat yaitu berat volume tanah menurun $1.120 \mathrm{gr} / \mathrm{cm}^{3}$, daya pegang air semakin meningkat $30.24 \%$, dan ruang pori tanah meningkat $57.74 \%$, sehingga agregat tanah menjadi baik. Dan untuk sifat kimia tanah, pemberian pupuk bokasih mampu memperbaiki sifat kimia tanah pada tanaman tomat yaitu C-organik $0.91 \%$ sangat rendah, $\mathrm{N}$-total tanah 0.32 $\%$ sedang, P-tersedia $37.25 \mathrm{ppm}$ sangat tinggi, dan K-tersedia 425.64 ppm sangat tinggi dan $\mathrm{pH}$ tanah menjadi 6.81 netral.

2. Pemberian dosis pupuk bokasih 20 ton/ha dapat meningkatkan sifat fisik dan kimia tanah secara optimal pada tanaman tomat. 


\section{Ucapan Terima Kasih}

Pada kesempatan ini penulis ingin mengucapkan terima kasih kepada semua pihak yang telah membantu dengan caranya masing-masing dalam melengkapi tulisan ini

\section{DAFTAR PUSTAKA}

Biadan Pusat Statistik. 2016. Survey Pertanian Produksi Tanaman Sayuran di Indonesia.BPS.Jakarta.http://does.google. com/viewer?q\&reachejs8 wdve6e8M;pdf. Disidir tanggal 30 oktober 2011

Cahyono.2008. Petunjuk Teknologi Pengolahan Hasil Hortikultura. Dinas Pertanian Tanaman Pangan Daerah Provinsi Jawa Timur, Surabaya.

Dinas Pertanian Kabupaten Ende. 2012. Hasil dan Produksi Tanaman Tomat.

Hamidah E. 2014. Analisis Pendapatan Usahatani Tomat (Licopersicum esculentum Mill.). Di Dusun Brumbun Desa Lamongrejo Kecamatan Ngimbang Kabupaten Lamongan. Saintis. Vol. 6 (2): 37-52.

Hanafiah, K.A. 2010. Dasar-Dasar Ilmu Tanah. PT. RajaGrafindo Persada. Jakarta.

Hartanto N. 2013. Ketersediaan Unsur Hara Tanaman Sawi Dengan Pemupukan Bokasih Daun Gamal Pada Tanah Rekreasi.

Nismawati.,Wulandari R.,Irmasari. 2013.

Pengaruh Pemberian Berbagai Dosis

Bokasih Terhadap Pertumbuhan Semai Kemiri (Aleurites mollucana (L) Willd.). Warta Rimba. Vol. 1 (1): 1-8

Nurlenawati, N., dkk. 2010. Respon Pertumbuhan dan Hasil Tanaman Tomat Terhadap Berbagai Dosis Pupuk Fosfar Dan Bokasih Jerami Limbah Jamur Merang. J. Agrika. Volume 4 Nomor 1 